\title{
The Impact of China's Acid Rain and Sulfur Dioxide Control Zones Policy on Industrial Sulfur Dioxide Emissions: A Panel Analysis
}

\begin{abstract}
Yujia Wu*
Abstract: In order to control sulfur dioxide $\left(\mathrm{SO}_{2}\right)$ emissions, the Chinese government in 1998 implemented the Acid Rain and Sulfur Dioxide Emission Control Zones policy (known as the Two Control Zone or TCZ policy). In a panel analysis of the impact of the TCZ policy on China's industrial $\mathrm{SO}_{2}$ emissions, two-way fixed-effects models show that it did not significantly reduce either per capita $\mathrm{SO}_{2}$ emissions or $\mathrm{SO}_{2}$ intensity in China. The study also reveals that instead of the traditional inverted U-shaped Environmental Kuznets Curve, the relationship between income growth and sulfur pollution in China favors an $\mathrm{N}$-shaped pattern. The empirical results indicate that the TCZ policy has not had a consistent, longterm impact on sulfur pollution control. This is in accord with previous studies and the actual situation in the two control zones. This paper presents two policy recommendations for improving the mitigation of $\mathrm{SO}_{2}$ pollution in China.
\end{abstract}

Keywords: sulfur dioxide, acid rain, two control zones, China, air pollution

\section{INTRODUCTION}

China's blistering economic growth has resulted in a rapid increase in energy consumption over the last two decades. In 2009, coal still represented more than 70 percent of China's total energy supply, and even the most optimistic alternative policy scenario from the International Energy Agency (IEA) showed that coal would still be used to meet more than 60 percent of China's total energy demand in 2030 (Cao,

\footnotetext{
* Yujia $\mathrm{Wu}$ is a consultant for the Secretariat of the North-East Asian Subregional Programme for Environmental Cooperation (NEASPEC) and the Subregional Office for East and North-East Asia of the United Nations Economic and Social Commission for Asia and the Pacific (SRO-ENEA, UNESCAP). She has a master's degree in international economics and international environmental policy from the University of California, San Diego. E-mail: wu5@un.org.
}

Manuscript received June 10, 2011; out for review June 16, 2011; review completed August 5, 2011; accepted August 8, 2011.

The Korean Journal of Policy Studies, Vol. 26, No. 2 (2011), pp. 77-100.

(C) 2011 by the GSPA, Seoul National University 
Garbaccio, \& Ho, 2009). In China, coal-fired power plants have been recognized as the main source of industrial $\mathrm{SO}_{2}$ emissions. As illustrated in graph 1 in appendix 1 , total $\mathrm{SO}_{2}$ emissions in China climbed rapidly in the last two decades, and China became the biggest emitter in 2005 with total $\mathrm{SO}_{2}$ emissions of 21 million tons.

In 1998, the Chinese government promulgated the Two Control Zone (TCZ) package of policies, resulting in the establishment of acid rain and sulfur dioxide control zones. The "two control zones" cover 1.09 million square kilometers, comprising 175 cities and districts in 27 provinces, which account for about 11.4 percent of China's territory (Xue, Chai, Duan, Chen, \& Li, 2002). The policy package includes the following provisions (Li \& Gao, 2002):

1. Any new coal mine with a sulfur content greater than 3.0 percent will be shut down; output of existing coal mines with a sulfur content greater than 3.0 percent will be limited.

2. The construction of new thermal power plants will not be approved in large and medium-size cities or their suburbs; for newly built or rebuilt thermal power plants, if the sulfur content in burning coal exceeds 1.0 percent, desulfurization facilities must be installed.

Since provinces in the two control zones received and executed the same package of polices at almost the same time, this paper will focus on the TCZ policy as a whole and its overall impact on China's industrial $\mathrm{SO}_{2}$ emissions.

\section{LITERATURE REVIEW}

Previous research on China's TCZ policy can be divided into two categories. The first, on mainstream $\mathrm{SO}_{2}$ control policies, traces the origins of the TCZ policy and studies the challenges and opportunities for implementing control policies within the two control zones. For example, Hao, Wang, Liu, and He (2000) reviewed the design of the two control zones and elaborated that the key control strategies were formulated on the basis of a life-cycle assessment of coal consumption. In addition, this paper indicated that due to the foreseeable huge increase in electricity consumption, driven by China's rapid economic growth, control of $\mathrm{SO}_{2}$ emissions would become an extremely tough task in the two control zones. Hence, it might be necessary to develop clean coal technologies to ensure the abatement of $\mathrm{SO}_{2}$ emissions in China.

Another study, conducted by Xue et al. (2002), summarized the designation and control strategies of the two control zones. Based on a review of socioeconomic and environmental conditions, the paper suggested follow-up actions for controlling $\mathrm{SO}_{2}$ 
emissions in the two zones, especially by increasing the emissions charge and installing desulfurization facilities for power plants.

A great many studies of this type have argued that the TCZ policy initially played a positive role in controlling $\mathrm{SO}_{2}$ emissions but that its positive impact gradually weakened. Li and Gao (2002) pointed out that although the TCZ policy has resulted in short-term success in mitigating acid deposition problems, it would not necessarily ensure that the $\mathrm{SO}_{2}$ emissions are steadily abated in the long run. They also argued that the TCZ policy could be considered a sound approach for avoiding a drastic rise in control costs but that additional policy tools are needed in order to enforce these measures. A similar argument was presented by Gao, Yin, Ai, and Huang (2009), who reviewed the development and implementation of $\mathrm{SO}_{2}$ control policies in China between 1996 and 2006. They found that although the TCZ policy contributed to achieving the $\mathrm{SO}_{2}$ emission control goal made by the 9th Five-Year Plan (1996-2000), the reduction in $\mathrm{SO}_{2}$ emissions failed to continue during the 10th Five-Year Plan (2001-2005).

The TCZ policy has also been addressed by a second type of literature, on $\mathrm{SO}_{2}$ policy optimization, which has evaluated command-and-control policies and market instruments based on cost and benefit analyses and tried to identify cost-effective policies for abating $\mathrm{SO}_{2}$ emissions in China. For instance, Cao et al. (2009) used a dynamic computable general equilibrium model to examine the costs and benefits of the implementation of two major policies in the two control zones-the small power plant shutdown, and fluidized gas desulfurization installation for key power plants. This study concluded that both policies imposed costs on the Chinese economy but that the costs were modest in comparison to the reductions in damages to human health and ecosystems.

Cofala et al. (2004) adopted the RAINS-Asia ${ }^{1}$ integrated assessment model for acidification in Asia to study the optimization routine that can be used to identify costeffective emissions control strategies for abating $\mathrm{SO}_{2}$ concentrations and sulfur deposition in Asia. However, this study only briefly reviewed the TCZ policy. The second type of literature also includes some studies of the tradable permit mechanism for controlling $\mathrm{SO}_{2}$ emissions in China, which usually offer only a short and simple discussion on the TCZ policy.

The first type of literature often draws conclusions based on descriptive studies and

1. RAINS (Regional Air Pollution Information and Simulation)-Asia Model was developed and applied for integrated assessment of future $\mathrm{SO} 2$ emissions in Asia. The model offers an opportunity to assess sulfur deposition and ecosystems protection levels resulting from different energy pathways and different emission control strategies. (Foell et. al, 1995) 
simple statistical trend analyses, while the second type of literature pays little attention to the TCZ policy. Unlike the earlier research, this paper will focus only on the TCZ policy, instead of studying overall $\mathrm{SO}_{2}$ abatement policies or selecting the optimal $\mathrm{SO}_{2}$ control policy for China. It will apply a panel analysis to assess the impact of the TCZ policy on industrial $\mathrm{SO}_{2}$ emissions in China.

\section{DATA SOURCE}

This paper uses Chinese province-level panel data from 1991 to 2007 to evaluate the effect of the TCZ policy on China's industrial $\mathrm{SO}_{2}$ emissions. Chongqing Province lacks six years of data because it did not become an administrative district until it was separated from Sichuan Province in 1997. In order to maintain consistency and avoid omitting data, this paper merges the data from Chongqing Province into the data from Sichuan Province between 1997 and 2007, considering these two provinces as one for the whole time frame. Data statistics are presented in tables 1 and 2 in appendix 1.

\section{METHODOLOGY}

It is clear that the impressive development of the Chinese economy has exerted huge pressures on its environmental capacity. It is supposed that per capita income growth in line with economic development in China should increase the demand for better environmental quality. This kind of relation between economic development and environmental quality has been addressed in a large body of literature. The Environmental Kuznets Curve (EKC), ${ }^{2}$ which indicates an inverted U-shaped curve for the income-inequality relationship, was popularized as a hypothesis analogous to the income-pollution relationship.

Almost all EKC studies (Stern \& Common, 2001) that are based on cross-country datasets support the inverted U-shaped relation between $\mathrm{SO}_{2}$ pollution and per capita income, which implies that, with economic growth, pollution should increase at first and then diminish once per capita income has attained a determined level. However, the EKC relationship does not automatically come from the increase in per capita income itself, but from exogenous public actions. Under the EKC hypothesis, the growth of per capita income could lead to an increase in environmental consciousness in a society, which could spur government to adopt environmental regulations, thereby

2. Dinda (2004) gives an overview of the EKC literature and background history. 
diminishing pollution.

Thus, in order to assess the specific impact of the TCZ policy on industrial $\mathrm{SO}_{2}$ emissions, empirical variables must be added to the EKC model in order to control for the Chinese government's overall regulation of $\mathrm{SO}_{2}$ emissions. The standard empirical model of $\mathrm{EKC}$ for $\mathrm{SO}_{2}$ emissions uses $\mathrm{SO}_{2}$ per capita $\left(\mathrm{SO}_{2} \mathrm{PC}\right)$ as the dependent variable; the independent variables include GDP per capita (GDPPC), quadratic term of GDP per capita (GDPPC_sq), and population density (pop_density).

The traditional inverted U-shaped EKC hypothesis has often been accepted by cross-country studies, which have predominated in the EKC literature. In recent years, however, an $\mathrm{N}$-shaped EKC relationship, which implies an increase in pollution levels after an initial decrease, has been increasingly reported for some pollution indicators in country- and location-specific studies. For example, Mazzaniti, Montini, and Zoboli (2007) studied the delinking trends of emission-related indicators in Italy at both sectoral and provincial levels. This study found mixed evidence supporting the EKC hypothesis. Some of the pollutants confirmed the inverted U-shaped EKC hypothesis, while others produced N-shaped curves. A case study by Diao, Zeng, Tam, and Tam (2009) showed a weak N-shaped relationship between industrial solid waste and GDP per capita in Jiaxing of Zhejiang Province, China. Llorca and Meunie (2009) also found an $\mathrm{N}$-shaped relationship between per capita income growth and per capita $\mathrm{SO}_{2}$ emissions in China. Therefore, this paper will introduce a cubic term of GDP per capita to capture a possible N-shaped pattern in the China-specific EKC. The baseline model is as follows:

\section{Baseline Model I}

$$
\begin{aligned}
S_{2} P C_{i t}= & \beta_{0}+\beta_{1} G D P P C_{i t}+\beta_{2} G D P P C_{i t}^{2}+\beta_{3} G D P P C_{i t}^{3}+\beta_{4} \text { pop_density }_{i t} \\
& +\beta_{5} \text { thermal_electricity }_{i t}+\beta_{6} \text { Treatment_98 } 8_{i t}+\sum_{1991}^{t} \delta \text { time }{ }_{t}+\alpha_{i}+\mu_{i t}
\end{aligned}
$$

On the right-hand side of Model I, a treatment dummy was introduced to capture the specific impact of the $\mathrm{TCZ}$ policy on $\mathrm{SO}_{2}$ emissions. The treatment dummy is set equal to 1 after the year 1998 for provinces in the two control zones, and equal to 0 before 1998 for all provinces. All data are taken from the China Statistical Year Book (19902008), so it is reasonable to assume that they are consistently measured over time.

The three variables GDPPC, GDPPC_sq, and pop_density, are empirical independent variables for the EKC hypothesis. GDPPC is used as an index to indicate economic growth or regional production for each province in China. Since China's economic activities, such as industrial production, consume large amounts of energy provided by 
coal, it is probable that higher GDP would lead to increased $\mathrm{SO}_{2}$ emissions. Models used here include population density (pop_density) as well, because a higher population density tends to intensify the negative impact of sulfur pollution. Hence, a densely populated province should have fewer pollution problems than a province that has the same income level but a lower population density. So we should expect to see a negative coefficient on this variable.

Apart from these empirical EKC variables, thermal-power-produced electricity (thermal_electricity) is also included in baseline model I, because thermal power plants are the main contributors to China's industrial $\mathrm{SO}_{2}$ emissions. For instance, coal is used to generate 80 percent of China's electricity, and in 2009, 49 percent of coal in China was consumed by electricity production. In this sense, thermal_electricity should gain a positive coefficient, indicating a positive correlation between $\mathrm{SO}_{2}$ per capita emission and thermal-power-produced electricity.

Besides $\mathrm{SO}_{2}$ emission per capita, $\mathrm{SO}_{2}$ emissions per $\mathrm{GDP}\left(\mathrm{SO}_{2} \mathrm{GDP}\right)$ can also be a valuable indicator of the effectiveness of the TCZ policy. It measures how many tons of $\mathrm{SO}_{2}$ emissions are generated per unit of GDP, thereby showing the $\mathrm{SO}_{2}$ intensity in China. The $\mathrm{SO}_{2}$ intensity can be considered as an indicator of the impact of sulfurrelated economic activities on the environment. In addition to baseline model I, a study on $\mathrm{SO}_{2}$ intensity will also be conducted as follows:

\section{Baseline Model II}

$$
\begin{aligned}
S O_{2} P G D P_{i t}= & \beta_{0}+\beta_{1} \text { SDPPC }_{i t}+\beta_{2} \text { pop_density }_{i t}+\beta_{3} \text { thermal_electricity }_{i t} \\
& +\beta_{4} \text { Treatment_98 }_{i t}+\sum_{1991}^{t} \delta \text { fime }_{t}+\alpha_{i}+\mu_{i t}
\end{aligned}
$$

There is no empirical evidence that improved $\mathrm{SO}_{2}$ intensity is expressed in the classic inverted U shape against per capita income. Therefore, model II excludes the quadratic and cubic terms of GDP per capita, leaving only GDPPC, pop_density and thermal_electricity as basic control variables.

Before finalizing the two models, we must first look carefully at the potential for reverse causality. This paper provides a specific test for the endogeneity problem in the section entitled Robustness Checks. The test results imply that reverse causality is indeed a concern in this model. In order to solve this problem, both models assign each observation its own time trend by using an interaction term between $\mathrm{id}^{3}$ and time to

3. The variable of id is created to represent individuals of the sample used by the two-way fixed-effects models in this paper. 
control the different rate of change in $\mathrm{SO}_{2}$ emissions between the treatment and control groups. After accounting for reverse causality problems, the two baseline models are as follows:

\section{Model I with Time Trend}

$$
\begin{aligned}
S O_{2} P C_{i t}= & \beta_{0}+\beta_{1} G D P P C_{i t}+\beta_{2} G D P P C_{i t}^{2}+\beta_{3} G D P P C_{i t}^{3}+\beta_{4} p \text { pop_density }{ }_{i t} \\
& +\beta_{5} \text { thermal_electricity }_{i t}+\beta_{6} \text { Treatment_98 }_{i t}+\sum_{1991}^{t} \delta\left(i d^{*} \text { time }\right)_{i t} \\
& +\alpha_{i}+\mu_{i t}
\end{aligned}
$$

\section{Model II with Time Trend}

$$
\begin{aligned}
S O_{2} P G D P_{i t}= & \beta_{0}+\beta_{1} \text { SDPPC }_{i t}+\beta_{2} \text { pop_density }_{i t}+\beta_{3} \text { thermal_electricity }_{i t} \\
& +\beta_{4} \text { Treatment_98 }_{i t}+\sum_{1991}^{t} \delta(\text { id*time })_{i t}+\alpha_{i}+\mu_{i t}
\end{aligned}
$$

Since observations are collected at the province level over time, there may be many unobserved factors that could influence $\mathrm{SO}_{2}$ emissions. Problems arise when these factors are also correlated with the decision to implement the TCZ policy. If we use random-effects or pooled-OLS methods, we must assume that there is no correlation between $\mathrm{SO}_{2}$ per capita and unobservable provincial variation. However, because each province has its own unique features and characteristics, it is difficult to defend this assumption. Hence, the safest way to address these factors is to remove them with a fixed-effects analysis. Tables 3 and 4 in appendix 2 present the results of Hausman tests for both models I and II. Because the tests indicate that we reject the null hypothesis, we can say that fixed-effects regression-rather than random-effects regression-is the preferred method.

\section{EMPIRICAL RESULTS}

\section{Model I}

Before running the baseline model, a simple two-way fixed-effects model without time dummies was conducted. Table 5 in appendix 3 shows that the TCZ policy has not had a significant effect on per capita $\mathrm{SO}_{2}$ emissions. After adding time dummies to knock down the overall time trend of $\mathrm{SO}_{2}$ emissions, the coefficient of the treatment 
variable for Model I became significant (table 6 in appendix 3) at the 10 percent level. However, the sign of the coefficient on the policy dummy is positive, which indicates that $\mathrm{SO}_{2}$ emissions per capita of provinces in the two control zones actually increased, compared to the emissions of provinces outside the zones. Moreover, after making an adjustment for time trends within each unit, as table 7 in appendix 3 illustrates, the treatment variable is not significant at either the 5 percent or 10 percent level in Model I. Interestingly, the negative GDPPC quadratic term and positive GDDPC cubic term indicate that there is an $\mathrm{N}$-shaped pattern for the relationship between income growth and industrial $\mathrm{SO}_{2}$ emissions in China (see graph 2 in appendix 3).

\section{Model II}

Table 8 in appendix 4 gives the regression outcome for the baseline model without time dummies, which suggests that the reduction in industrial $\mathrm{SO}_{2}$ emissions in the control zones is $24.15 \mathrm{~kg}$ more per 10,000 yuan (around US\$1,500) than in provinces outside of the control zones. After applying the time dummy in the model, the marginal effect of the treatment dummy remained highly significant, but the scale of coefficient was reduced from $24.15 \mathrm{~kg}$ per 10,000 yuan to $15.39 \mathrm{~kg}$ per 10,000 yuan (see table 9 in appendix 4).

The fixed-effects model with time adjustment for each unit gave a significant coefficient for $\mathrm{SO}_{2}$ intensity (see table 10 in appendix 4), which indicates that rather than a reduction in $\mathrm{SO}_{2}$ intensity, the TCZ policy resulted in an average increase in $\mathrm{SO}_{2}$ emissions by $12.72 \mathrm{~kg}$ per 10,000 yuan in the two control zones. The fixed-effects result also shows that growth in GDP per capita will increase $\mathrm{SO}_{2}$ intensity with an average growth rate of $10.62 \mathrm{~kg}$ per 10,000 yuan. Similarly, the regression result implies that each increase in thermal-power-generated electricity by 100 million $\mathrm{kWh}$ will increase $\mathrm{SO}_{2}$ intensity by $0.04 \mathrm{~kg}$ per 10,000 yuan.

\section{ROBUSTNESS CHECK}

\section{Endogeneity}

It is important to point out that the TCZ policy is not a random trial and that those provinces with high $\mathrm{SO}_{2}$ emissions and serious acid rain problems would have been likely policy targets. If reverse causality is an issue, one would expect the rate of change of per capita $\mathrm{SO}_{2}$ and $\mathrm{SO}_{2}$ intensity between the treatment group and the control group to be different before and after the implementation of TCZ policy. 
In order to test this assumption, the dataset was collapsed by group and year, and pre-treatment T-tests were conducted for the means of change of both $\mathrm{SO}_{2} \mathrm{PC}$ and $\mathrm{SO}_{2} \mathrm{PGDP}$ variables between the control group and treatment group. In appendix 5, tables 11 and 12 demonstrate that there is no significant difference between control group and treatment group before policy implementation for either per capita $\mathrm{SO}_{2}$ or $\mathrm{SO}_{2}$ intensity. However, the T-tests have only weak power due to the low degrees of freedom. As shown in the two tables, the means of change of per capita $\mathrm{SO}_{2}$ and $\mathrm{SO}_{2}$ intensity in the treatment group are almost three times that of the mean of change in the control group. Graphs 3 and 4 also provide visual evidence that, before the implementation of the TCZ policy, per capita $\mathrm{SO}_{2}$ started at a higher level with a faster growth rate in the treatment group, while $\mathrm{SO}_{2}$ intensity started at a higher level with a faster reduction rate in the treatment group than in the control group.

Additionally, by applying a Probit model, we can discover the common features among observations in the treatment group. Regression outcomes shown in table 13 demonstrate that all independent variables are key factors in determining which provinces are included in the TCZ policy. In other words, provinces within the control zones are characterized by high existing $\mathrm{SO}_{2}$ pollution, high GDP per capita, and high population density.

These characteristics exactly reflect the selection criteria identified by the Plan on Identifying the Acid Rain Control Zone and Sulfur Dioxide Pollution Control Zone, issued by the State Environmental Protection Administration in 1996. In this plan, selection criteria for areas to be included in the acid rain control zone were (1) current $\mathrm{pH}$ level of precipitation less than 4.5, (2) sulfur deposition exceeding critical loads, and (3) presence of a large amount of $\mathrm{SO}_{2}$ emissions. Criteria for inclusion in the $\mathrm{SO}_{2}$ pollution control zone were (1) recent annual average concentrations of $\mathrm{SO}_{2}$ exceeding level II of the national standard, (2) daily average concentration of $\mathrm{SO}_{2}$ exceeding level III of the national standard, and (3) presence of a large amount of $\mathrm{SO}_{2}$ emissions. (For detailed information on national ambient air quality standards, please refer to table 14 in appendix 5.) Thus the policy specifically targeted areas that received more $\mathrm{SO}_{2}$ emissions and acid rain. As a result, the policy analysis seems to be affected by selection bias, leading to a reverse causality problem. The third item in each set of selection criteria is very vague, without a quantity specified for what constitutes "a large amount" of $\mathrm{SO}_{2}$ emissions. Thus, some scholars have cast doubts on the effectiveness of the TCZ policy, and some have even argued that the control standards were just used to prioritize $\mathrm{SO}_{2}$ control efforts that would divert extra resources and attention to those cities and regions. 


\section{Autocorrelation}

Another problem that must be considered is autocorrelation in the error term for both model I and model II. Autocorrelation, if it exists, would not result in "wrong" answers for coefficient estimates, but would magnify the standard error and generate an incorrect confidence interval. After running a regression of the residuals of both $\mathrm{SO}_{2} \mathrm{PC}$ and $\mathrm{SO}_{2} \mathrm{PGDP}$ on their lags, this study found that there are three lags with a significant impact on the $\mathrm{SO}_{2} \mathrm{PC}$ 's and $\mathrm{SO}_{2}$ GDP's residuals (see tables 15 and 16 in appendix 5). To correct this, Newey-West standard errors were applied to account for the autocorrelation (table 17). As stated earlier, the estimates of the treatment dummy are still not significant in model I. Although the coefficient of the treatment dummy becomes negative, the estimation is not statistically significant.

\section{CONCLUSION AND POLICY IMPLICATIONS}

One interesting finding of this empirical study is that there is an N-shaped relationship, rather than the traditional inverted U-shaped EKC, between per capita income and per capita $\mathrm{SO}_{2}$ emissions in China. Sulfur pollution starts to decline after reaching a threshold of 17,529 yuan, and begins to increase again after per capita income increases to a second threshold of 54,430 yuan. ${ }^{4}$ One possible explanation of the Nshaped pattern is that the delinking of sulfur pollution from income growth is only temporary in the two control zones. The $\mathrm{SO}_{2}$ emissions in the zones were initially reduced by the package of policies. After a while, however, its effectiveness faded away, and continuous economic growth began to worsen sulfur pollution again. This interpretation is accord with earlier studies (in the first category of literature described above), which argued that $\mathrm{SO}_{2}$ control policies in China can become weaker and less effective in the long run.

In addition, the regression results of models I and II indicate that the TCZ policy has no significant impact on sulfur pollution in the control zones, for provinces in the zones experience declining trends neither for $\mathrm{SO}_{2}$ emission per capita nor for $\mathrm{SO}_{2}$ intensity at the average level, compared to provinces that are not included in the zones.

4. This result is obtained from the cubic polynomial function derivative, and the two thresholds can be obtained from the following equations:

$$
\tau_{1}=\frac{-2 \beta_{2}-\sqrt{4\left(\beta_{2}\right)^{2}-12 \beta_{1} \beta_{3}}}{6 \beta_{3}}, \tau_{2}=\frac{-2 \beta_{2}-\sqrt{4\left(\beta_{2}\right)^{2}-12 \beta_{1} \beta_{3}}}{6 \beta_{3}}
$$


These results are in accord with the actual situation for the past two decades. In fact, Chinese environmental reports have stated that the TCZ policy did not fundamentally prevent the growth of $\mathrm{SO}_{2}$ pollution in China, especially from 2000 to 2005.

According to government reports on environmental policy, specific requirements of the TCZ policy did not come into practice until after 2000. The main reason is that energy efficiency was seriously underfunded, and the Chinese government emphasized economic growth over improving energy efficiency and environmental protection (Gao et al, 2009). In China, an electricity shortage emerged in 2002 and worsened in 2004. In the summer of 2004, 24 provinces experienced a brownout, which caused widespread disruption of industrial production and huge economic losses. Because of power shortages, the plan to shut down small coal-fired power units was not carried out. On the contrary, some small units that had been shut down resumed operation, and many new small coal-fired power units were built in a short period of time. As a result, $\mathrm{SO}_{2}$ emissions from coal-fired power plants increased by 70 percent, from 6.54 million tons in 2001 to 11.12 million tons in 2005(SEPA 2002, 2006). Rather than dropping in 2000-2005 by 10 percent (to 18 million tons) as planned, by 2005 national $\mathrm{SO}_{2}$ emissions had actually risen to 21 million tons, almost 17 percent above the goal. (Gao et. al 2009)

The temporary effectiveness and eventual failure of the TCZ policy imply that two key components need to be strengthened for the further development of sulfur pollution control policies. First, the government should adopt cost-effective policies that ensure long-term sulfur pollution control because they reduce implementation costs and therefore create more incentives for stakeholders to implement the policies. Second, in line with the implementation of an $\mathrm{SO}_{2}$ control policy, China has to reduce its high reliance on coal for electricity generation and develop a cleaner energy mix. The significantly positive correlation between thermal-power-produced electricity and $\mathrm{SO}_{2}$ intensity estimated by model II reflects the fact that China's electricity production relies heavily on coal, which is the main source of $\mathrm{SO}_{2}$ emission.

Shealy and Dorian (2010) predicted that the energy demand will at least double in China between 2005 and 2030, and coal consumption in particular will hit 5 billion tons in 2025 , even if the economy sustains only a moderate 6.5 percent average GDP growth rate. Therefore, it is urgent for China to diversify energy resources and exploit renewable resources like wind energy to guarantee a stable electricity supply without worsening sulfur pollution. 
88 The Impact of China's Acid Rain and Sulfur Dioxide Control Zones Policy on Industrial Sulfur Dioxide Emissions

\section{APPENDIX 1: $\mathrm{SO}_{2}$ POLLUTION}

Graph 1. Total Chinese $\mathrm{SO}_{2}$ Emissions 1991-2007

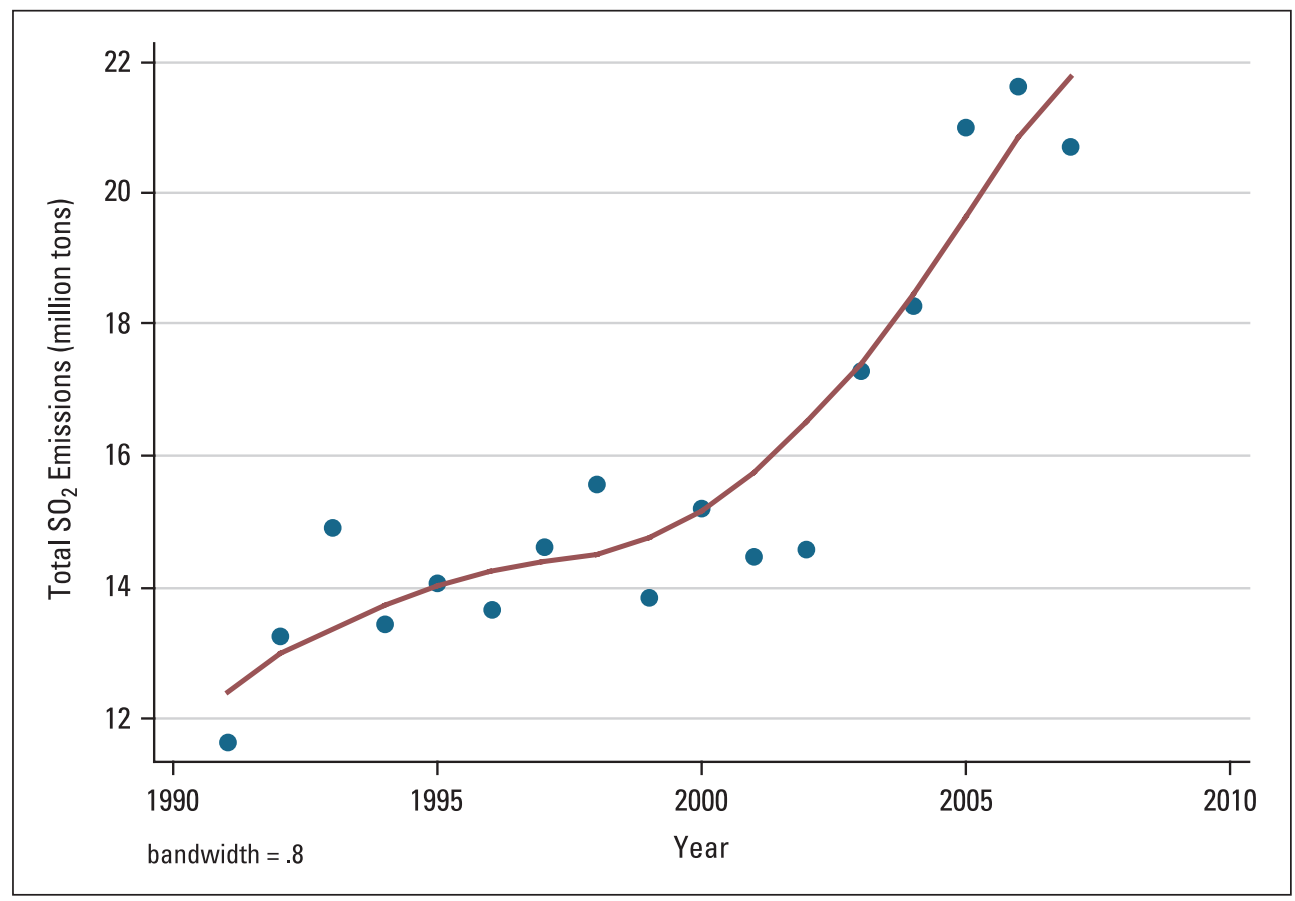




\section{APPENDIX 2: METHODOLOGY AND DATA DESCRIPTION}

Table 1. Variable Descriptions

\begin{tabular}{l|l|l}
\hline Dependent variable & Description & Unit \\
\hline $\mathrm{SO}_{2}$ per capita (SO2PC) & $\begin{array}{l}\text { China's industrial SO2 emissions per person, } \\
\text { calculated as total SO2 emissions divided by total } \\
\text { population }\end{array}$ & $\mathrm{kg} /$ person \\
\hline $\mathrm{SO}_{2}$ per GDP (SO2PGDP) & $\begin{array}{l}\text { China's industrial SO2 emissions per GDP, } \\
\text { calculated as total SO2 emissions divided by total } \\
\text { GDP }\end{array}$ & $\mathrm{kg} / 10,000$ yuan \\
\hline GDP per capita (GDPPC) & $\begin{array}{l}\text { China's GDP per person, calculated as total GDP } \\
\text { divided by total population }\end{array}$ & 10,000 yuan/person \\
\hline $\begin{array}{l}\text { GDP per capita squared } \\
\text { (GDPPC_sq) }\end{array}$ & Quadratic term of GDP per capita & $(10,000 \text { yuan/person })^{2}$ \\
\hline $\begin{array}{l}\text { GDP per capita cubed } \\
\text { (GDPPC_cube) }\end{array}$ & Cubic term of GDP per capita & $(10,000 \text { yuan/person })^{3}$ \\
\hline Population density (pop_density) & Number of people per square kilometer & person/km² \\
\hline $\begin{array}{l}\text { Thermal production of electricity } \\
\text { (thermal_electricity) }\end{array}$ & Thermal production of electricity & 100 million $\mathrm{kWh}$ \\
\hline \begin{tabular}{l} 
Treatment (treatment_98) \\
\hline
\end{tabular} & Dummy variable of “two control zone" policy & \\
\hline
\end{tabular}

Table 2. Variable Statistics

\begin{tabular}{l|c|r|r|r|r}
\hline Variable & \multicolumn{1}{|c|}{$\#$} & \multicolumn{1}{c|}{ Mean } & \multicolumn{1}{c|}{ Std dev. } & \multicolumn{1}{c|}{ Min } & \multicolumn{1}{c}{ Max } \\
\hline SO2PC & 510 & 13.82916 & 9.573403 & 0 & 60.25645 \\
\hline SO2PGDP & 510 & 27.48502 & 32.51312 & 0 & 343.3522 \\
\hline GDPPC & 510 & 0.9211395 & 0.9186862 & 0.0874088 & 6.560199 \\
\hline GDPPC_sq & 510 & 1.690828 & 4.255604 & 0.0076403 & 43.03621 \\
\hline GDPPC_cube & 510 & 5.136292 & 22.29954 & 0.0006678 & 282.3261 \\
\hline Pop_density & 510 & 365.104 & 461.2879 & 3.88647 & $2,996.774$ \\
\hline Thermal_electricity & 507 & 418.3202 & 423.7342 & 0.01 & 2691.43 \\
\hline Treatment_98 & 510 & 0.4509804 & .4980798 & 0 & 1 \\
\hline
\end{tabular}

\# = number of observations. 
Table 3. Hausman Test for Model I

\begin{tabular}{l|c|c|c|c}
\hline \multirow{2}{*}{} & \multicolumn{2}{|c|}{ Coefficients } & \multirow{2}{*}{$\begin{array}{c}(\mathrm{b}-\mathrm{B}) \\
\text { Difference }\end{array}$} & $\begin{array}{c}\text { sqrt(diag(v_b_v_B)) } \\
\text { S.E. }\end{array}$ \\
\cline { 2 - 3 } & $\mathrm{f})$ & $(\mathrm{B})$ & -.0168411 & .1140979 \\
\hline GDPPC & 8.518388 & 8.535229 & .1772388 & .0471168 \\
\hline GDPPC_square & -2.973362 & -3.150601 & .0105191 &. \\
\hline GDPPC_cube & .299272 & .2887529 & -.000402 & .0002976 \\
\hline thermal_el $\sim y$ & .0045431 & .004945 & -.0169959 & .0060387 \\
\hline pop_density & -.0190064 & -.0020105 & .2506676 & .1467039 \\
\hline treatment_98 & -.8830301 & -1.133698 & & \\
\hline
\end{tabular}

$\mathrm{b}=$ consistent under $\mathrm{Ho}$ and $\mathrm{Ha}$; Obtained from xtreg

$\mathrm{B}=$ inconsistent under $\mathrm{Ha}$, efficient under $\mathrm{Ho}$; obtained from xtreg

Test: Ho: difference in coefficients not systematic

chi2(6) $\left.=(b-B)^{\prime}\left[v \_b \_v \_B\right)^{\wedge}(-1)\right](b-B)$

$=-11.23$ chi $2<0==>$ model fitted on these data fails to meet the asymptotic assumptions of the Hausman test see suest for a generalized test

Table 4. Hausman Test for Model II

\begin{tabular}{l|c|c|c|c}
\hline \multirow{2}{*}{} & \multicolumn{2}{|c|}{ Coefficients } & (b-B) \\
\cline { 2 - 4 } & $(\mathrm{b})$ & $(\mathrm{B})$ & Difference & $\begin{array}{c}\text { sqrt(diag(v_b_v_B)) } \\
\text { Se }\end{array}$ \\
\hline GDPPC & -7.035875 & -4.666058 & -2.369817 & 1.945515 \\
\hline thermal_el $\sim y$ & -.0077276 & -.0089265 & .0011989 & .0026758 \\
\hline pop_density & .0607377 & .0043656 & .0563721 & .0243351 \\
\hline treatment_98 & -24.14697 & -21.98025 & -2.166713 &. \\
\hline
\end{tabular}

$\mathrm{b}=$ consistent under $\mathrm{Ho}$ and $\mathrm{Ha}$; Obtained from xtreg

$\mathrm{B}=$ inconsistent under $\mathrm{Ha}$, efficient under $\mathrm{Ho}$; obtained from xtreg

Test: Ho: difference in coefficients not systematic

chi2(4) $\left.=(\text { b-B)'[v_b_v_B })^{\wedge}(-1)\right](b-B)$

$=-553.44$ chi $2<0=\Rightarrow$ model fitted on these data fails to meet the asymptotic assumptions of the Hausman test; see suest for a generalized test 


\section{APPENDIX 3: EMPIRICAL RESULTS FOR MODEL I}

Table 5. Two-Way Fixed-Effects Regression of Baseline Model I without Time Dummies

\begin{tabular}{|c|c|}
\hline Independent variable & Dependent variable: S02PC \\
\hline GDPPC & $8.518^{* * *} \quad(1.560)$ \\
\hline GDPPC_sq & $-2.973^{* * *} \quad(0.637)$ \\
\hline GDPPC_cube & $0.299 * * * \quad(0.076)$ \\
\hline Thermal_electricity & $0.00454^{* * *}(0.00123)$ \\
\hline Pop_density & $-0.0190^{* * *} \quad(0.00676)$ \\
\hline Treatment_98 & $(0.670)$ \\
\hline Constant & $15.02^{* * *}$ \\
\hline Observations & 507 \\
\hline Number of id & 30 \\
\hline R-squared & 0.230 \\
\hline RMSE & 4.634 \\
\hline
\end{tabular}

Standard errors are given in parentheses.

${ }^{* * *} \mathrm{p}<0.01,{ }^{* *} \mathrm{p}<0.05,{ }^{*} \mathrm{p}<0.1$

Table 6. Two-Way Fixed-Effects Regression of Baseline Model I with Time Dummies

\begin{tabular}{l|cc}
\hline Independent variable & Dependent variable: SO2PC \\
\hline GDPPC & $12.09^{* * *}(3.408)$ \\
\hline GDPPC_sq & $-4.346^{* * *}$ & $(1.052)$ \\
\hline GDPPC_cube & $0.410^{* * *}$ & $(0.108)$ \\
\hline Thermal_electricity & $0.00265^{* *}$ & $(0.00125)$ \\
\hline Pop_density & -0.008 & $(0.00697)$ \\
\hline Treatment_98 & $1.841^{*}$ & $(0.990)$ \\
\hline Constant & $11.09^{* * *}$ & $(2.553)$ \\
\hline Observations & 507 \\
\hline Number of id & 0.307 \\
\hline R-squared & 30.000 \\
\hline RMSE & 4.472 \\
\hline
\end{tabular}

Standard errors are given in parentheses.

${ }^{* * *} p<0.01,{ }^{* *} p<0.05,{ }^{*} p<0.1$ 
Graph 2. N-Shaped EKC Hypothesis for the Income to SO2 Pollution Relation in China

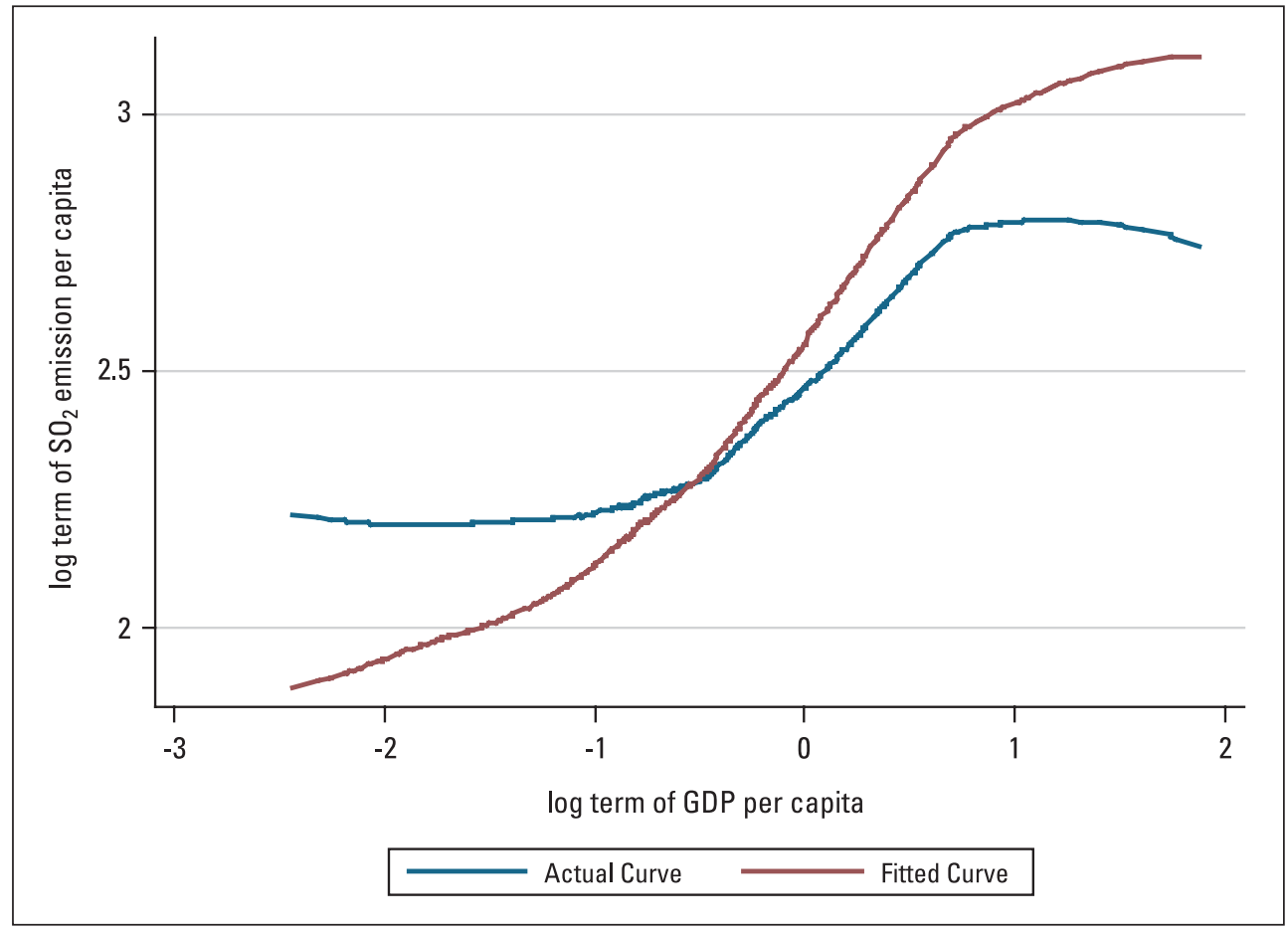

Table 7. Two-Way Fixed-Effects Adjusted Regression of Model I with id*time Term

\begin{tabular}{l|cl}
\hline Independent variable & Dependent variable: SO2PC \\
\hline GDPPC & $21.66^{* * *}$ & $(3.697)$ \\
\hline GDPPC_sq & $-4.411^{* * *}$ & $(1.043)$ \\
\hline GDPPC_cube & $0.346^{* * *}$ & $(0.105)$ \\
\hline Thermal_electricity & 0.000897 & $(0.00248)$ \\
\hline Pop_density & 0.009 & $(0.01720)$ \\
\hline Treatment_98 & 0.67 & $(0.963)$ \\
\hline Constant & 7.2 & $(11.780)$ \\
\hline Observations & \multicolumn{2}{|c}{507} \\
\hline Number of id & \multicolumn{2}{|c}{30} \\
\hline R-squared & \multicolumn{2}{|c}{-} \\
\hline RMSE & \multicolumn{2}{|c}{4.05} \\
\hline
\end{tabular}

Standard errors are given in parentheses.

${ }^{* * *} \mathrm{p}<0.01,{ }^{* *} \mathrm{p}<0.05,{ }^{*} \mathrm{p}<0.1$

The Korean Journal of Policy Studies 


\section{APPENDIX 4: EMPIRICAL RESULTS FOR MODEL II}

Table 8. Two-Way Fixed-Effects Regression of Baseline Model II without Time Dummies

\begin{tabular}{|c|c|c|}
\hline Independent variable & \multicolumn{2}{|c|}{ Dependent variable: S02PGDP } \\
\hline GDPPC & $-7.036^{* *}$ & (2.901) \\
\hline Thermal_electricity & -0.00773 & (0.005) \\
\hline Pop_density & $0.0607^{* *}$ & $(0.026)$ \\
\hline Treatment_98 & $-24.15^{* * *}$ & (2.699) \\
\hline Constant & $26.02^{* * *}$ & $(8.601)$ \\
\hline Observations & \multicolumn{2}{|c|}{507} \\
\hline Number of id & \multicolumn{2}{|c|}{30} \\
\hline R-squared & \multicolumn{2}{|c|}{0.311} \\
\hline RMSE & \multicolumn{2}{|r|}{21} \\
\hline
\end{tabular}

Standard errors are given in parentheses.

${ }^{* * *} \mathrm{p}<0.01,{ }^{* *} \mathrm{p}<0.05,{ }^{*} \mathrm{p}<0.1$

Table 9. Two-Way Fixed-Effects Regression of Baseline Model II with Time Dummies

\begin{tabular}{l|cc}
\hline Independent variable & \multicolumn{2}{|c}{ Dependent variable: SO2PGDP } \\
\hline GDPPC & $8.228^{* *}$ & $(3.447)$ \\
\hline Thermal_electricity & -0.0061 & $(0.005)$ \\
\hline Pop_density & -0.00289 & $(0.025)$ \\
\hline Treatment_98 & $-15.39^{* * *}$ & $(4.009)$ \\
\hline Constant & $65.27^{* * *}$ & $(8.707)$ \\
\hline Observations & 507 \\
\hline Number of id & 0.518 \\
\hline R-squared & 30.000 \\
\hline RMSE & 18 \\
\hline
\end{tabular}

Standard errors are given in parentheses.

${ }^{* * *} p<0.01,{ }^{* *} p<0.05,{ }^{*} p<0.1$ 
94 The Impact of China's Acid Rain and Sulfur Dioxide Control Zones Policy on Industrial Sulfur Dioxide Emissions

Table 10. Two-Way Fixed-Effects Adjusted Regression of Model Il with id*time Term

\begin{tabular}{l|cc}
\hline \multicolumn{1}{|c|}{ Dependent variable: SO2PGDP } \\
\hline Independent variable & $10.62^{* *}$ & $(4.799)$ \\
\hline GDPPC & $0.0365^{* * *}$ & $(0.009)$ \\
\hline Thermal_electricity & -0.0156 & $(0.059)$ \\
\hline Pop_density & $12.72^{* * *}$ & $(3.628)$ \\
\hline Treatment_98 & 40.160 & $(37.550)$ \\
\hline Constant & \multicolumn{2}{|c}{507} \\
\hline Observations & \multicolumn{2}{|c}{30.000} \\
\hline Number of id & \multicolumn{2}{|c}{16} \\
\hline R-squared & \multicolumn{2}{|c}{16} \\
\hline RMSE & \multicolumn{2}{|c}{} \\
\hline
\end{tabular}

Standard errors are given in parentheses.

${ }^{* * *} \mathrm{p}<0.01,{ }^{* *} \mathrm{p}<0.05,{ }^{*} \mathrm{p}<0.1$ 


\section{APPENDIX 5: ROBUSTNESS CHECKS}

T-Test: Pre-Treatment Comparison of Mean of Change between Control Group and Treatment Group

Table 11. Pre-Treatment T-Test for Change of SO2 per Capita between Control Group and Treatment Group

\begin{tabular}{|c|c|c|c|c|c|c|}
\hline \multicolumn{7}{|c|}{ Two-sample t-test with equal variances } \\
\hline Group & obs & Mean & Std. Err. & Std. Dev & \multicolumn{2}{|c|}{ [95\% Conf. Interval] } \\
\hline 0 & 7 & .1480796 & 1.85819 & 4.916309 & -4.398748 & 4.694907 \\
\hline 1 & 7 & .4418322 & .4684325 & 1.239356 & -.7043808 & 1.588045 \\
\hline combined & 14 & .2949559 & .9214734 & 3.447838 & -1.695766 & 2.285678 \\
\hline diff & & -.2937525 & 1.916325 & & -4.469065 & 3.88156 \\
\hline \multicolumn{5}{|c|}{$\begin{aligned} \operatorname{diff} & =\operatorname{mean}(0)-\operatorname{mean}(1) \\
\text { Ho: diff } & =0\end{aligned}$} & \multicolumn{2}{|r|}{$\begin{aligned} t & =-0.1533 \\
\mathrm{~m} & =\quad 12\end{aligned}$} \\
\hline \multicolumn{2}{|c|}{$\begin{array}{c}\text { Ha: diff }<0 \\
\operatorname{Pr}(T<t)=0.4404\end{array}$} & \multicolumn{3}{|c|}{$\begin{array}{c}\text { Ha: diff } !=0 \\
\operatorname{Pr}(|t|>|t|)=0.8807\end{array}$} & \multicolumn{2}{|c|}{$\begin{array}{c}\text { Ha: diff }>0 \\
\operatorname{Pr}(T>t)=0.5596\end{array}$} \\
\hline
\end{tabular}

Table 12. Pre-Treatment T-Test for Change of S02 per GDP between Control Group and Treatment Group

\begin{tabular}{|c|c|c|c|c|c|c|}
\hline \multicolumn{7}{|c|}{ Two-sample t-test with equal variances } \\
\hline Group & obs & Mean & Std. Err. & Std. Dev. & \multicolumn{2}{|c|}{ [95\% Conf. Interval] } \\
\hline $\begin{array}{l}0 \\
1\end{array}$ & $\begin{array}{l}7 \\
7\end{array}$ & $\begin{array}{l}-2.905581 \\
-6.623227\end{array}$ & $\begin{array}{l}6.05293 \\
3.392511\end{array}$ & $\begin{array}{c}16.01455 \\
8.975741\end{array}$ & $\begin{array}{l}-17.71657 \\
-14.9244\end{array}$ & $\begin{array}{l}11.9054 \\
1.677949\end{array}$ \\
\hline combined & 14 & -4.764404 & 3.37293 & 12.62035 & -12.05118 & 2.522367 \\
\hline diff & & 3.717646 & 6.938811 & & -11.40072 & 18.83602 \\
\hline \multicolumn{5}{|c|}{$\begin{aligned} \text { diff } & =\operatorname{mean}(0)-\operatorname{mean}(1) \\
\text { Ho: } \operatorname{diff} & =0\end{aligned}$} & \multicolumn{2}{|c|}{$\begin{aligned} t & =0.5358 \\
\text { degrees of freedom } & =\quad 12\end{aligned}$} \\
\hline \multicolumn{2}{|c|}{$\begin{array}{c}\text { Ha: diff }<0 \\
\operatorname{Pr}(\mathrm{T}<\mathrm{t})=0.6990\end{array}$} & \multicolumn{3}{|c|}{$\begin{array}{c}\text { Ha: diff } !=0 \\
\operatorname{Pr}(|t|>|t|)=0.6019\end{array}$} & \multicolumn{2}{|c|}{$\begin{array}{c}\text { Ha: diff }>0 \\
\operatorname{Pr}(\mathrm{T}>\mathrm{t})=0.3010\end{array}$} \\
\hline
\end{tabular}


Graph 3. Mean of SO2 per Capita in Control Group and Treatment Group, 1991-2007

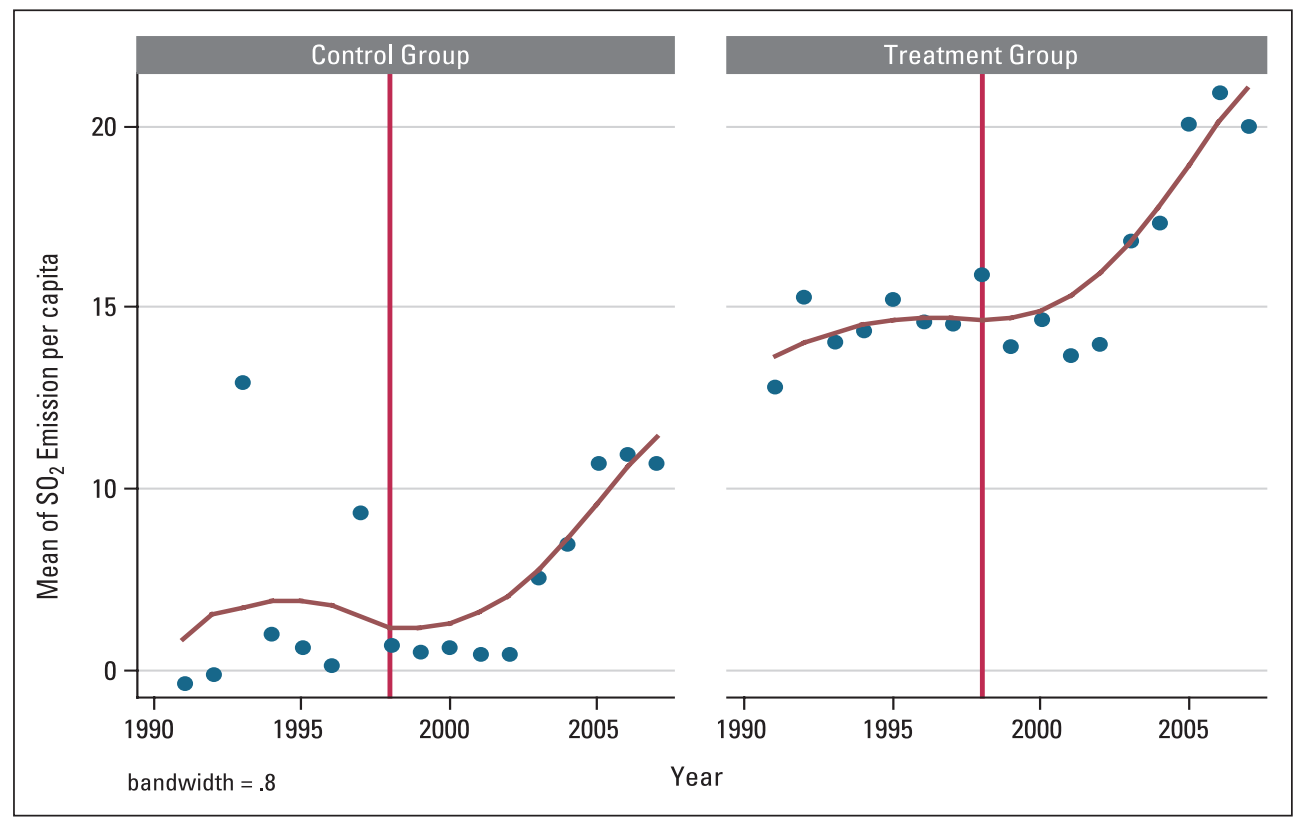

Graph 4. Mean of SO2 Intensity in Control Group and Treatment Group, 1991-2007

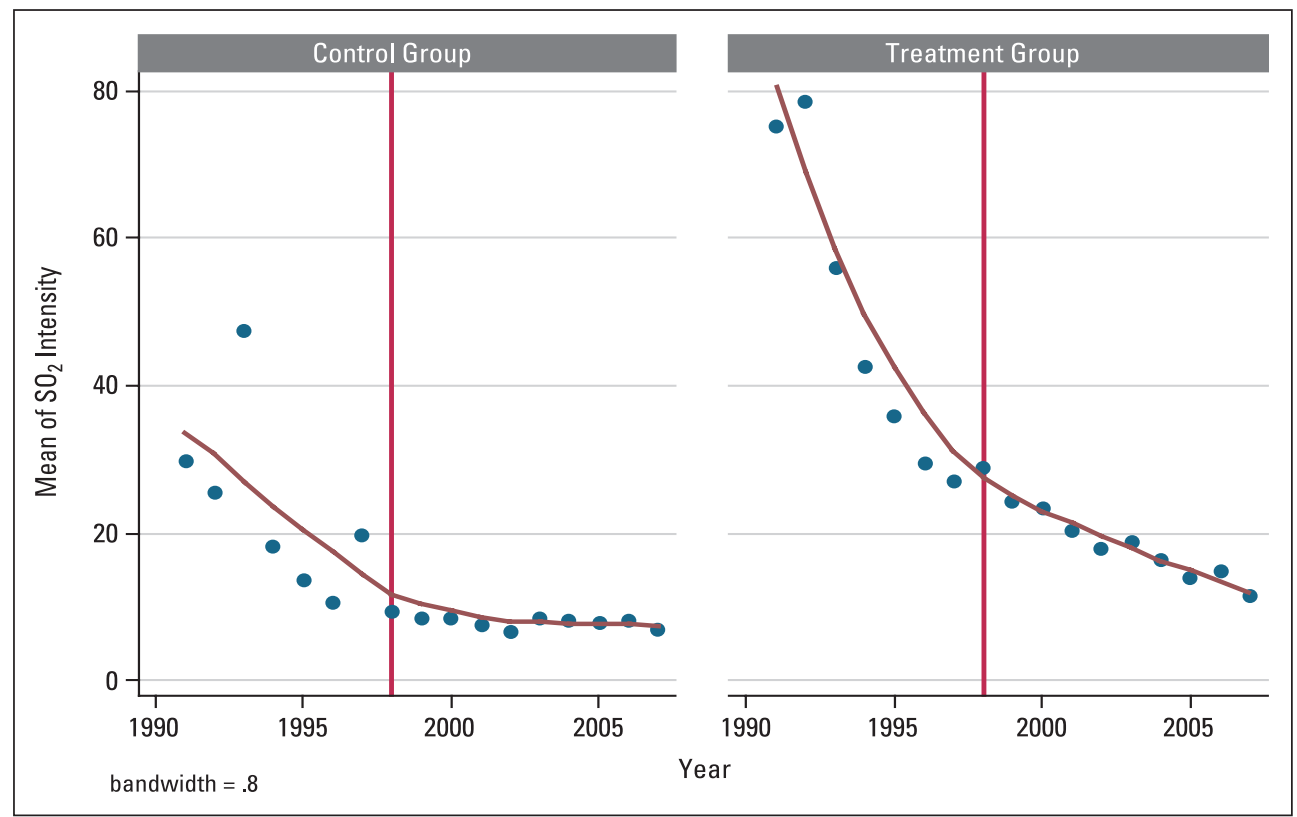

The Korean Journal of Policy Studies 
Table 13. Probit Model for Treatment Dummy Variable

\begin{tabular}{l|ll}
\hline Independent variable & Dependent variable: treatment_98 \\
\hline GDPPC & $0.330^{* * *}$ & $(0.116)$ \\
\hline Thermal_electricity & $0.000957^{* * *}$ & $(0.000)$ \\
\hline Pop_density & $-0.000616^{* * *}$ & $(0.000)$ \\
\hline SO2PC & $0.0800^{* * *}$ & $(0.01340)$ \\
\hline SO2PGDP & $-0.0236^{* * *}$ & $(0.00492)$ \\
\hline Constant & $-1.058^{* * *}$ & $(0.15700)$ \\
\hline Observations & \multicolumn{2}{|c}{507} \\
\hline Number of id & \multicolumn{2}{|c}{} \\
\hline R-squared & \multicolumn{2}{|c}{} \\
\hline
\end{tabular}

Standard errors are given in parentheses.

${ }^{* * *} p<0.01,{ }^{* *} p<0.05,{ }^{*} p<0.1$

Table 14. National Standards for SO2 Concentration in China

\begin{tabular}{c|c|c|c}
\hline \multirow{2}{*}{ Time unit } & \multicolumn{3}{|c}{ Concentration limit $(\mu \mathrm{g} / \mathrm{m3})$} \\
\cline { 2 - 4 } & Level I & Level II & Level III \\
\hline Annual average & 0.02 & 0.06 & 0.10 \\
\hline Daily average & 0.05 & 0.15 & 0.25 \\
\hline Hourly average & 0.15 & 0.50 & 0.70 \\
\hline
\end{tabular}

Source: State Administration of Environmental Protection of China, 1996.

Table 15. Test of Autocorrelation for Model I

\begin{tabular}{l|cc}
\hline Independent variable & $0.746^{* * *}$ & Dependent variable: residual of SO2PC \\
\hline Residual_lag1 & $0.157^{* * *}$ & $(0.0401)$ \\
\hline Residual_lag2 & $0.0934^{* * *}$ & $(0.0349)$ \\
\hline Residual_lag3 & 0.0126 & $(0.0338)$ \\
\hline Residual_lag4 & 0.0112 & $(0.153)$ \\
\hline Constant & \multicolumn{2}{|c}{377} \\
\hline Observations & \multicolumn{2}{|c}{0.907} \\
\hline R-squared & \multicolumn{2}{|c}{2.974} \\
\hline RMSE & \multicolumn{2}{|c}{} \\
\hline
\end{tabular}

Standard errors are given in parentheses.

${ }^{* * *} p<0.01,{ }^{* *} p<0.05,{ }^{*} p<0.1$ 
Table 16. Test of Autocorrelation for Model II

\begin{tabular}{l|cc}
\hline Independent variable & \multicolumn{2}{|c}{ Dependent variable: residual of S02PGDP } \\
\hline Residual_lag1 & $0.700^{* * *}$ & $(0.0398)$ \\
\hline Residual_lag2 & $0.110^{* * *}$ & $(0.0301)$ \\
\hline Residual_lag3 & $0.0486^{* *}$ & $(0.0202)$ \\
\hline Residual_lag4 & 0.0245 & $(0.0193)$ \\
\hline Constant & 0.0309 & $(0.350)$ \\
\hline Observations & \multicolumn{2}{|c}{377} \\
\hline R-squared & \multicolumn{2}{|c}{0.896} \\
\hline RMSE & \multicolumn{2}{|c}{6.7930} \\
\hline
\end{tabular}

Standard errors are given in parentheses.

*** $p<0.01,{ }^{* *} p<0.05,{ }^{*} p<0.1$

Table 17. Two Models with Newey-West Standard Errors, Time Dummies Not Reported

\begin{tabular}{l|c|c}
\hline Independent variable & Dependent variable: SO2PC & Dependent variable: SO2PGDP \\
\hline GDPPC & $-85.57^{* * *}$ & $\begin{array}{c}-13.68^{* * *} \\
(2.761)\end{array}$ \\
\hline \multirow{2}{*}{ GDPPC_sq } & $(12.940)$ & $\mathrm{N} / \mathrm{A}$ \\
\hline GDPPC_cube & $29.48^{* * *}$ & $\mathrm{~N} / \mathrm{A}$ \\
\hline Thermal_electricity & $(5.541)$ & 0.0000918 \\
& $-2.902^{* * *}$ & $(0.004)$ \\
\hline \multirow{2}{*}{ Pop_density } & $(0.625)$ & 0.00401 \\
& $0.00814^{* *}$ & $(0.00377)$ \\
\hline \multirow{2}{*}{ Treatment_98 } & $(0.003)$ & -5.773 \\
& 0.000312 & $(3.897)$ \\
\hline \multirow{2}{*}{ Constant } & $(0.004)$ & $41.39^{* * *}$ \\
& 2.187 & $(4.912)$ \\
\hline Observations & $(2.997)$ & 507 \\
\hline
\end{tabular}

Standard errors are given in parentheses.

${ }^{* * *} \mathrm{p}<0.01,{ }^{* *} \mathrm{p}<0.05,{ }^{*} \mathrm{p}<0.1$ 


\section{REFERENCES}

Cao, J., Garbaccio, R., \& Ho, M. 2009. Benefits and costs of $\mathrm{SO}_{2}$ abatement policies in China. Review of Environmental Economics and Policy, 3(2): 231-250.

Cofala, J., Amann, M., Gyarfas, F., Schoepp, W., Boudri, J. C., Hordijk, L., Kroeze, C., Li, J. F., Lin, D., Panwar, T. S., \& Gupta, S. 2004. Journal of Environmental Management, 72: 149-161.

Diao, X. D., Zeng, S. X., Tam, C. M., \& Tam, V. W. Y. 2009. EKC analysis for studying economic growth and environmental quality: A case study in China. Journal of Cleaner Production, 17: 541-548.

Dinda, S. 2004. Environmental Kuznets curve hypothesis: A survey. Ecological Economics, 49: 431-455.

Foell, W., Amann, M., Carmichael, G., Chadwick, M., Hettelingh, J., Hordijk, L., \& Zhao, D. 1995. RAINS-Asia: an assessment model for air pollution in Asia. Project Report of The International Institute for Applied Systems Analysis (IIASA). Retrieved from http://www.iiasa.ac.at/ rains/asia1/index.html

Gao, C. I., Yin, H. Q., Ai, N. S., \& Huang, Z. W. 2009. Historical analysis of $\mathrm{SO}_{2}$ pollution control policies in China. Environmental Management, 43: 447-457.

Hao, J. M., Wang, S. X., Liu, B. J., \& He, K. 2000. Designation of acid rain and $\mathrm{SO}_{2}$ control zones and control policies in China. Journal of Environmental Science and Health A, 35(10): 1901-1914.

. 2001. Plotting of acid rain and sulfur dioxide pollution control zones and integrated control planning. Water, Air, and Soil Pollution, 130: 259-264.

Li, W., \& Gao, J. X. 2002. Acid deposition and integrated zoning control in China. Environmental Management, 30(2): 169-182.

Llorca, M., \& Meunie, A. 2009. $\mathrm{SO}_{2}$ emissions and the environmental Kuznets curve: The case of Chinese provinces. Journal of Chinese Economic and Business Studies, 7(1): 1-16.

Mazzanti, M., Montini, A., \& Zoboli, R. 2007. Economic dynamics, emission trends and the EKC hypothesis: New evidence using NAMEA and provincial panel data for Italy (Fondazione Eni Enrico Mattei Working Paper No. 24). Milan: Fondazione Eni Enrico Mattei.

National Bureau of Statistics of China. China Statistical Yearbooks. 2002-2008. China Statistics Press. Retrieved from http://www.stats.gov.cn/tjsj/ndsj/

Shealy, M., \& Dorian, J. P. 2010. Growing Chinese coal use: Dramatic resource and environmental implications. Energy Policy, 38: 2116-2122.

State Administration of Environmental Protection of China. 1996. Ambient air quality standard (in Chinese). Retrieved from http://szems.szhec.gov.cn/hjbz/200907/ 
P020090708507826303718.pdf.

State Environmental Protection Administration of China. China Environmental Yearbooks. 2002 \& 2006. China Environmental Science Press. Retrieved from http://www.mep.gov.cn/zwgk/hjtj/qghjtjgb/

State Environmental Protection Administration of China. Plan on identifying the acid rain control zone and sulfur dioxide pollution control zone (in Chinese). 1996. Retrieved from http://www.mep.gov.cn/gkml/zj/wj/200910/t20091022_172231. htm.

Stern, D. I., \& Common, M. S. 2001. Is there a Kuznets curve for sulfur? Journal of Environmental Economics and Management, 41: 162-178.

Xue, Z. G., Chai, F. H., Duan, N., Chen, Y. Z., \& Li, J. D. 2002. Trend and control strategy of acid rain and sulfur dioxide emissions in the "Two Control Zones" (in Chinese). Research and Approach, 11: 1003-2355. 